\title{
Influence of vitamin D receptor polymorphisms on biochemical markers of mineral bone disorders in South African patients with chronic kidney disease
}

\author{
Bala Waziri ${ }^{*} \mathbb{B}$, Therese Dix-Peek, Caroline Dickens, Raquel Duarte and Saraladevi Naicker
}

\begin{abstract}
Background: It remains unclear whether genetic factors may explain the reported variation in the levels of biochemical markers of chronic kidney disease mineral and bone disorders (CKD- MBD) across ethnic groups. Therefore, the aim of this study was to examine the influence of vitamin D receptor (VDR) polymorphisms on secondary hyperparathyroidism and its association with vitamin D levels in black and white South African study participants.

Methods: This was a cross sectional study involving 272 CKD stage 3- 5D patients and 90 healthy controls. The four major VDR polymorphisms (Bsm 1, Fok 1, Taq 1, and Apa1) were genotyped using the polymerase chain reaction- restriction fragment length polymorphism (PCR -RFLP) method. In addition, biochemical markers of CKD-MBD were measured to determine their associations with the four VDR polymorphisms.

Results: With the exception of Taq I polymorphism, the distribution of the VDR polymorphisms differed significantly between blacks and whites. In hemodialysis patients, the Bb genotype was significantly associated with moderate secondary hyperparathyroidism $(\mathrm{OR}, 3.88 ; 95 \mathrm{Cl} 1.13-13.25, p=0.03)$ and severe hyperparathyroidism $(\mathrm{OR}, 2.54 ; 95 \mathrm{Cl}$ $1.08-5.96, p=0.03$ ). This was consistent with the observed higher levels of median parathyroid hormone, fibroblast growth factor 23 and mean phosphate in patients with $\mathrm{Bb}$ genotype. This candidate risk genotype (Bb) was over represented in blacks compared to whites (71.0\% versus $55.6 \%, p<0.0001)$. In an unadjusted regression model, FokFf genotype was found to be significantly associated with the risk of developing severe vitamin D deficiency $<15 \mathrm{ng} / \mathrm{ml}$ $(\mathrm{OR}, 1.89 ; 95 \mathrm{Cl} 1.17-3.07, p=0.01)$.

Conclusion: The VDR Bb genotype is an independent predictor of developing secondary hyperparathyroidism in patients with end stage kidney disease. In addition, study participants with FokFf genotype are at increased of developing severe 25 -hydroxyvitamin $\mathrm{D}[25(\mathrm{OH}) \mathrm{D}]$ deficiency.
\end{abstract}

Keywords: Chronic kidney disease, Secondary hyperparathyroidism, VDR polymorphisms

\section{Background}

Vitamin D deficiency has been linked to various disease conditions and poor clinical outcomes [1-3]. The widespread consequences of vitamin D deficiency have been partly attributed to the ubiquitous distribution of the vitamin D receptor [4]. The vitamin D receptor (VDR) plays a vital role in mediating the effects of the biologically active form of vitamin D (1, 25, OH-D); therefore it is plausible

\footnotetext{
* Correspondence: balawaziri@gmail.com

Department of Internal Medicine, Faculty of Health Sciences, University of the Witwatersrand, Johannesburg, South Africa
}

that variations in these receptors will modulate the consequences associated with vitamin D deficiency [5]. In 1994, Morrison et al. [6] were the first to report an association between VDR polymorphisms and bone metabolism, showing that the common allelic variants in the VDR encoding genes can predict differences in bone density in healthy individuals [6]. Subsequently, several researchers have explored this relationship in CKD populations with emphasis on the calcium/ PTH/ calcitriol axis [7, 8]. BsmI polymorphism (BB genotype) has been associated with slower progression of secondary hyperparathyroidism and 
normal levels of calcitriol in pre dialysis CKD patients, and lower levels of parathyroid hormone (PTH) in hemodialysis, and a greater reduction in PTH levels in response to a single bolus of calcitriol therapy compared to patients with bb genotype $[8,9]$. However, contrary to earlier studies, findings from subsequent studies on the associations between VDR polymorphisms and markers of mineral bone disease have been inconsistent. For instance, some studies reported no difference in PTH levels between the various Bsm I genotypes [10, 11], while Chudek et al. reported significantly lower levels of calcitriol in patients with BB genotype [12]. Similarly, some studies have linked other VDR polymorphisms to mineral bone metabolism in hemodialysis patients. The VDR Fok I polymorphism (FF genotype) was reported to be associated with higher PTH levels [13].

Furthermore, the existence of racial disparities in abnormal markers of CKD-MBD and the better survival paradox in African Americans compared to white dialysis patients may be explained partly by the racial differences in the distribution of VDR polymorphisms and VDR receptor activation therapy. Most of these studies were conducted on European, Asian and American CKD populations, while studies from Africa were largely on non CKD populations. Therefore, in line with ongoing efforts to greater understanding of the mechanisms behind racial disparities in markers of CKD- MBD, we aimed to explore the variations in the VDR polymorphisms between black and white African CKD patients and their relationship with markers of mineral bone disorders.

\section{Methods}

This was a cross sectional study involving 272 CKD stage 3-5D patients and 90 healthy controls. The study protocol was approved by the Health Research and Ethics committee (HREC) of the University of the Witwatersrand; clearance certificate number M141016. All participants gave written informed consent prior to enrolment. Exclusion criteria included active malignancies, primary hyperparathyroidism, genetic related calcium disorders such as autosomal dominant hypercalciuric hypocalcemia, use of bisphosphonates, aged $<18$ years, and patients who withheld consent.

Information on participants' demographic characteristics, duration on dialysis and use of medications related to CKD-MBD were obtained. Determination of race was based on self report by the participants.

\section{Laboratory measurements}

Plasma intact PTH was measured by an electrochemiluminescence immunoassay (ECLIA) run on a Cobas 6000 auto analyzer (Roche Diagnostics, Mannheim, Germany).
FGF23 was measured using an enzyme-linked immunosorbent assay kit from EMD Millipore Corporation (Billerica, MA, USA). Assay lower detect limit was $3.2 \mathrm{pg} / \mathrm{ml}$.

Plasma 25(OH) D was measured using the high performance liquid chromatography (HPLC) kit (Recipe, Munich, Germany). HPLC was used to selectively measure 25(OH)D2 and $25(\mathrm{OH}) \mathrm{D} 3$ at a wave length of $264 \mathrm{~nm}$. The intra and inter assay coefficients of variation $(\mathrm{CVs})$ were $<5 \%$. Our institutional laboratory is a participating member in the vitamin D external quality assurance scheme (DEQAS).

Serum calcium, phosphate and alkaline phosphatase were measured using the ADVIA 1800 centaur auto analyzer (Siemens Diagnostics, Tarrytown, USA). The albumin corrected serum calcium was determined using the formula: corrected calcium $(\mathrm{mmol} / \mathrm{L})=$ calcium measured $(\mathrm{mmol} / \mathrm{L})+0.02[40$-albumin $(\mathrm{g} / \mathrm{L})]$.

Serum creatinine was measured by a modified Jaffe reaction and GFR was estimated using the four- variable Modified Diet Renal Disease (MDRD) equation [14]: GFR $\left(\right.$ in $\mathrm{mL} / \mathrm{min}$ per $\left.1.73 \mathrm{~m}^{2}\right)=175 \times \mathrm{SCr}(\exp [-1.154]) \times$ Age $(\exp [-0.203]) \times(0.742$ if female $) \times(1.21$ if black $)$.

Other biochemical parameters were determined using routine laboratory techniques.

\section{Genotyping}

DNA was extracted from whole blood using the Maxwell DNA purification kit (Promega AS1010, USA). Using appropriate primers obtained DNA products were amplified for ApaI (Foward: 5' CAGAGCATGGACAGGGAGC AAG 3' and Reverse: 5' GCAACTCCTCATGGCTG AGGTCTCA 3 ' with $65^{\circ} \mathrm{C}$ annealing temperature), BsmI (Forward: 5' CAACCAAGACTACAAGTACCGCGTC AGTGA 3' and Reverse: 5' AACCAGCGGGAAGAGGTC AAGGG 3 'with $65{ }^{\circ} \mathrm{C}$ as an annealing temperature), FokI (Forward: 5' AGCTGGCCCTGGCACTGACT CTTGCTCT 3' and Reverse: 5' ATGGAAACACCTT GCTTCTTCTCCCTC 3 ' with $67{ }^{\circ} \mathrm{C}$ annealing temperature), and TaqI (Forward: 5' CAGAGCATGGAC AGGGAGCAAG 3' and Reverse: 5'GCAACTCCTC ATGGCTGAGGTCTCA $3^{\prime}$ at an annealing temperature of $65{ }^{\circ} \mathrm{C}$ ) VDR polymorphisms. The PCR products were then digested with enzymes ApaI, BsmI, FokI, and TaqI (New England Biolabs, Beverly, MA, USA) according to the supplier's protocol. Digestions for BsmI and TaqI were at $65{ }^{\circ} \mathrm{C}$ left overnight, and $3 \mathrm{~h}$ at $25{ }^{\circ} \mathrm{C}$ for $\mathrm{ApaI}$, while FokI was incubated at $37{ }^{\circ} \mathrm{C}$ for $3 \mathrm{~h}$. Restricted products were electrophoresed on either $10 \%$ polyacrylamide or $1.5 \%$ agarose gels and then visualized by the Gel Doc TM EZ imager (Bio-Rad systems, USA). Genotypes were scored based on the presence or absence of a restriction site for the enzymes BsmI, ApaI, and TaqI at the 3' 
untranslated region and FokI at the N-terminal region of the gene.

\section{Statistical analysis}

The Fisher's exact test was utilized to compare differences in the frequency of genotypic distribution between groups. Based on the distribution of data, an independent $\mathrm{t}$ - test or Wilcoxon rank -sum test were used to compare continuous variables between two groups, while one- way ANOVA or Kruskal -Wallis tests were used for more than two groups. Both univariate and multivariable logistic regression models were used to determine the association between VDR genotypes, secondary hyperparathyroidism and vitamin D deficiency. A backward selection procedure was used to fit the multiple regression model, which started with all potential predictor variables and subsequently removed the variables that had $p$ values above the specified $P=0.20$. However, variables that are known to be biologically plausibly associated with secondary hyperparathyroidism were forced into the model despite not meeting inclusion criteria based on the stepwise approach. A post estimation test for Goodness of Fit of the models was carried out using Hosmer -Lemeshow goodness of fit test.
In the comparisons of the means and medians of the circulating markers of CKD-MBD across the genotypes, the $P$ values for distribution between homozygous dominant and heterozygous genotypes were further determined separately due to the smaller numbers of the homozygous recessive.

A $p$-value of less 0.05 was considered statistically significant at the $95 \%$ confidence interval. All analyses were performed using STATA version 12 (STATA Corp., TX, and USA).

\section{Results}

\section{Description of the study population}

A total of 362 participants (272 CKD patients and 90 controls) were recruited for this study. The CKD group comprised 156 CKD stage 5D and 116 CKD stages 3-5 patients. In the control group, 39 participants were selfidentified as whites, 60 as blacks, and one Indian. The CKD group comprised 73 whites, 175 blacks and 21 Indians. Fifteen patients were excluded from the genetic analysis due to failed genotyping (Fig. 1). Patients on haemodialysis were on three times weekly, $4 \mathrm{~h}$ sessions of haemodialysis using polysulphone membranes and bicarbonate dialysate. Most of the patients were dialyzed with a dialysate calcium concentration of $1.50 \mathrm{mmol} / \mathrm{L}$,

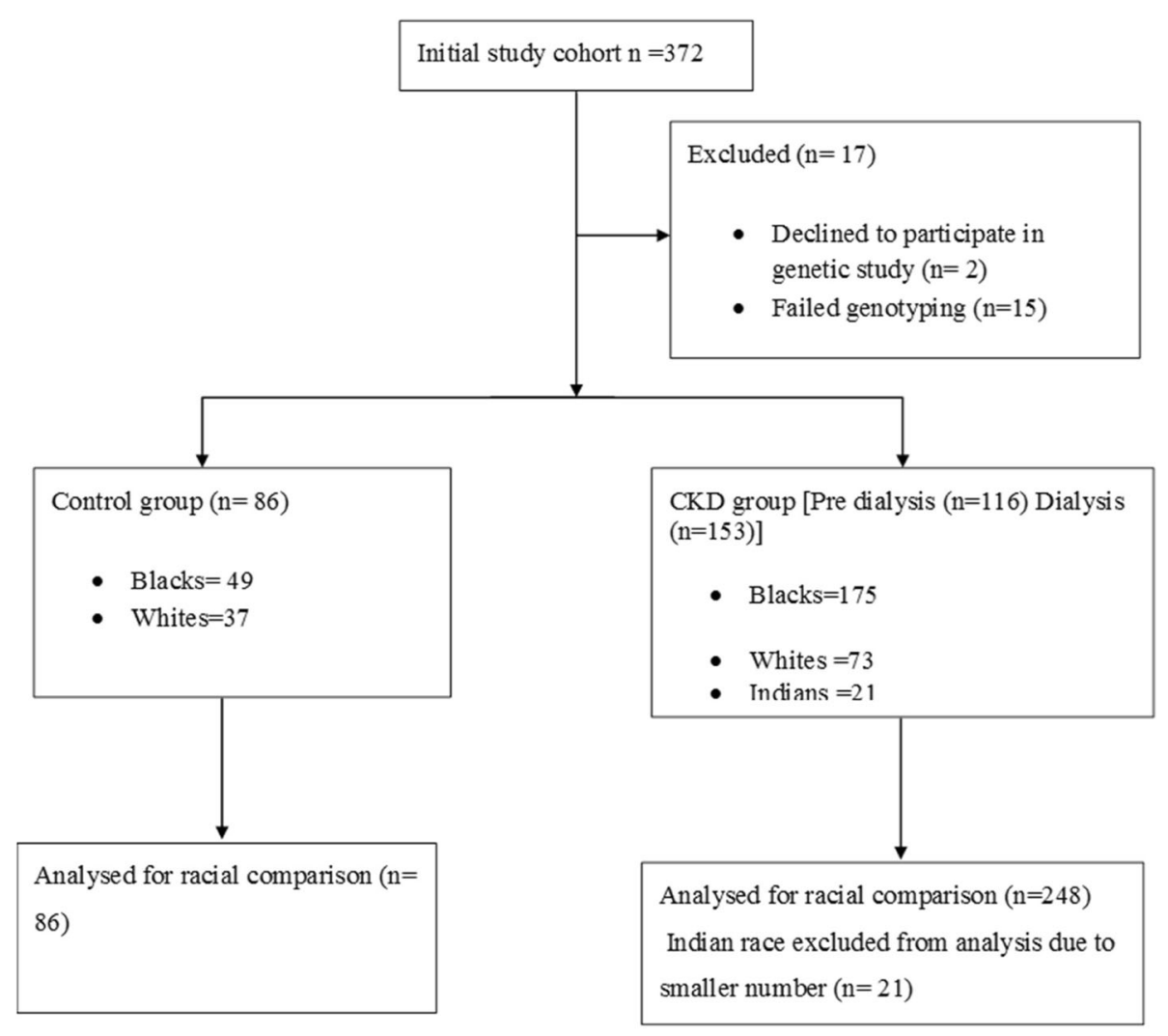

Fig. 1 Participant disposition and recruitment flow chart 
which is usually modified based on serum levels of calcium. The blood and dialysis flow rates are generally $300-400 \mathrm{mls} / \mathrm{min}$ and $500 \mathrm{mls} / \mathrm{min}$, respectively, as previously reported [15].

Table 1 shows the study participants characteristics and ethnic distribution of the VDR polymorphisms (Bsm I, FokI, ApaI and Taq I). In the VDR polymorphisms, blacks had significantly higher proportion of $\mathrm{Bb}$ genotype than whites $(71.0 \%$ versus $55.6 \%)$, and lower frequency of BB genotype (24.1\% versus $44.4 \%)$. Overall, the most common genotype was Bb (65.4\%). Similarly, the distribution in FokI andTaq I genotypes differed significantly between the groups; FF was more frequent in blacks, while Ff genotype was the most prevalent in whites. There was no significant ethnic variation in the distribution of the ApaI genotype. With the exception of Apa I genotype, the genotype distributions did not violate Hardy-Weinberg equilibrium.

Table 1 Participants characteristics and genotype frequencies by race

\begin{tabular}{llll}
\hline Parameters & Black $(n=224)$ & White $(n=110)$ & P-value \\
\hline Age (years) & $46.5 \pm 12.9$ & $54.4 \pm 17.5$ & $<0.0001$ \\
Gender n (\%) & & & \\
Male & $111(49.6 \%)$ & $60(54.5 \%)$ & 0.74 \\
Female & $113(50.4 \%)$ & $50(45.5 \%)$ & \\
25- O HD (ng/ml) & $25.8 \pm 12.1$ & $23.1 \pm 11.9$ & 0.048 \\
PTH (pg/ml) & $214(61-872)$ & $112(30-364)$ & 0.001 \\
Calcium (mmol/l) & $2.22 \pm 0.25$ & $2.29 \pm 0.18$ & 0.06 \\
TAP (U/L) & $120(88-190)$ & $110(74-145)$ & 0.14 \\
Phosphate (mmol/l) & $1.29 \pm 0.47$ & $1.48 \pm 0.49$ & 0.003 \\
FGF 23 (ng/ml) & $59(23-307)$ & $80(28-521)$ & 0.20 \\
VDR genotypes & & & \\
Bsm I & & & \\
BB & $54(24.1 \%)$ & $48(43.6 \%)$ & P $<0.0001$ \\
Bb & $159(71.0 \%)$ & $62(56.4 \%)$ & \\
bb & $11(4.9 \%)$ & $0(0.00 \%)$ & \\
Fok I & & & \\
FF & $151(67.4 \%)$ & $38(34.6 \%)$ & P $<0.0001$ \\
Ff & $71(31.7 \%)$ & $69(62.7 \%)$ & \\
ff & $2(0.89 \%)$ & $3(2.73 \%)$ & \\
Apa I & & & \\
AA & $94(42.0 \%)$ & $40(36.4 \%)$ & \\
Aa & $127(56.7 \%)$ & $69(62.7 \%)$ & \\
aa & $3(1.34 \%)$ & $1(0.91 \%)$ & \\
Taq I & & & \\
TT & & & \\
Tt & & & \\
tt & & & \\
\hline
\end{tabular}

Table 2 shows the distribution of the four VDR polymorphisms (Bsm I, FokI, ApaI and Taq I) between CKD patients and healthy controls, and the odds ratio of developing severe $25(\mathrm{OH})$ D severe deficiency $(<15 \mathrm{ng} /$ $\mathrm{ml})$. The frequencies of these genotypes did not differ significantly between the CKD and control groups. Ff genotype showed a significant increase in odds of developing severe $25(\mathrm{OH})$ D deficiency (OR, 1.89; $95 \mathrm{CI}$ 1.17-3.07, $p=0.01$ ); a similar trend was found with combined $\mathrm{Ff}+\mathrm{ff}$ genotypes (OR, 1.91; $95 \mathrm{CI} 1.18-3.08, p=$ 0.008 ). The remaining genotypes were not significantly associated with severe $25(\mathrm{OH}) \mathrm{D}$ deficiency.

Table 2 Distribution of VDR polymorphisms among CKD and control groups and the odds ratios for developing severe 25 -hydroxyvitamin D severe deficiency $(<15 \mathrm{ng} / \mathrm{ml})$

\begin{tabular}{clllll}
\hline $\begin{array}{lllll}\text { VDR } \\
\text { genotypes }\end{array}$ & Controls & CKD & p-value & OR (95\%Cl) & P-value \\
\hline Bsm I & $N=84$ & $N=268$ & & & \\
BB & $23(27.4 \%)$ & $87(32.5 \%)$ & 0.05 & 1.00 (reference) & \\
Bb & $55(65.5 \%)$ & $176(65.7 \%)$ & & $0.85(0.51-1.42)$ & 0.55 \\
bb & $6(7.14 \%)$ & $5(1.87 \%)$ & & $0.28(0.03-2.32)$ & 0.24
\end{tabular}

Dominant model

$\begin{array}{llllll}\mathrm{BB} & 23(27.4 \%) & 87(32.5 \%) & & & \\ \mathrm{Bb}+\mathrm{bb} & 61(72.6 \%) & 181(67.5 \%) & 0.38 & 0.83(0.50-1.37) & 0.46 \\ \text { Fok I } & N=86 & N=266 & & & \\ \mathrm{FF} & 45(52.3 \%) & 152(57.1 \%) & 0.47 & 1.00 \text { (reference) } & \\ \mathrm{Ff} & 39(45.4 \%) & 111(41.7 \%) & & 1.89(1.17-3.07) & 0.01 \\ \mathrm{ff} & 2(2.3 \%) & 3(1.1 \%) & & 2.52(0.41-15.59) & 0.32\end{array}$

Dominant model

$\begin{array}{llllll}\text { FF } & 45(52.3 \%) & 152(57.1 \%) & 0.43 & 1.00 \text { (reference) } & \\ \mathrm{Ff}+\mathrm{ff} & 41(47.7 \%) & 114(42.9 \%) & & 1.91(1.18-3.08) & 0.008 \\ \text { Apa I } & N=83 & N=269 & & & \\ \text { AA } & 32(38.6 \%) & 112(41.6 \%) & 0.50 & 1.00 \text { (reference) } & \\ \text { Aa } & 51(61.4 \%) & 152(56.5 \%) & & 1.44(0.88-2.37) & 0.15 \\ \text { aа } & 0(0.0 \%) & 5(1.86 \%) & & 2.33(0.37-14.57) & 0.37\end{array}$

Dominant model

$\begin{array}{llllll}\text { AA } & 32(38.6 \%) & 112(41.6 \%) & 0.70 & 1.00 \text { (reference } & \\ \text { Aa +aa } & 51(61.4 \%) & 157(59.0 \%) & & 1.46(0.89-2.40) & 0.13 \\ \text { Taq I } & \mathrm{N}=84 & \mathrm{~N}=268 & & & \\ \mathrm{TT} & 37(44.1 \%) & 146(54.5 \%) & 0.05 & 1.00 \text { (reference) } & \\ \mathrm{Tt} & 42(50.0 \%) & 95(35.5 \%) & & 1.00(0.61-1.65) & 0.99 \\ \mathrm{tt} & 5(6.0 \%) & 27(10.1 \%) & & 0.76(0.31-1.87) & 0.60\end{array}$

Dominant model

\begin{tabular}{llllll}
$\pi T$ & $37(44.1 \%)$ & $146(54.5 \%)$ & 0.06 & & \\
$\mathrm{Tt}+\mathrm{tt}$ & $47(56.0 \%)$ & $122(45.5 \%)$ & & $0.96(0.59-1.53)$ & 0.85 \\
\hline
\end{tabular}

$O R$ odds ratio, $C I$ confidence interval, $C K D$ chronic kidney disease, $\mathrm{p}$-value ${ }^{\mathrm{a}}$ for comparison of genotype frequencies between control and CKD groups, VDR $=$ vitamin $\mathrm{D}$ receptor 
Table 3 Levels of markers of CKD-MBD across various VDR genotypes

\begin{tabular}{|c|c|c|c|c|c|}
\hline \multirow{2}{*}{$\begin{array}{l}\text { Variable } \\
B s m \text { I }\end{array}$} & \multicolumn{3}{|l|}{ Genotypes } & \multirow[t]{2}{*}{$p$-value } & \multirow[t]{2}{*}{ P-value } \\
\hline & $\mathrm{BB}(n=87)$ & $\mathrm{Bb}(n=176)$ & $\mathrm{bb}(n=5)$ & & \\
\hline 25-OH D (ng/ml) & $21(14-33)$ & $25(16-34)$ & $27(19-31)$ & 0.30 & 0.14 \\
\hline PTH (pg/ml) & $231(111-593)$ & $553(197-1230)$ & $169(134-214)$ & $<0.001$ & $<0.001$ \\
\hline Calcium (mmol/l) & $2.24 \pm 0.21$ & $2.21 \pm 0.26$ & $2.15 \pm 0.25$ & 0.49 & 0.32 \\
\hline Corrected ca (mmol/l) & $2.20 \pm 0.75$ & $2.21 \pm 0.64$ & $2.20 \pm 0.10$ & 0.99 & 0.98 \\
\hline Phosphate (mmol/l) & $1.27 \pm 0.49$ & $1.43 \pm 0.49$ & $1.0 \pm 0.33$ & 0.002 & 0.01 \\
\hline TAP $(U / L)$ & $121(83-153)$ & $113(88-173)$ & $80(57-141)$ & 0.373 & 0.91 \\
\hline FGF 23 & $95(34-414)$ & $157(52-1191)$ & $33(22-35)$ & 0.047 & 0.08 \\
\hline \multicolumn{6}{|l|}{ Medications } \\
\hline Calcium carbonate & $37(42.5)$ & $89(50.6)$ & $2(40.0)$ & 0.19 & 0.07 \\
\hline Alfacalcidol & $28(32.2)$ & $80(45.5)$ & $1(20.0)$ & 0.09 & 0.047 \\
\hline Caco3 (mg/day) & $3643 \pm 802$ & $3577 \pm 744$ & $3750 \pm 1060$ & 0.94 & 0.84 \\
\hline Alfacalcidol ( $\mu \mathrm{g} /$ week) & $2.25 \pm 1.22$ & $1.81 \pm 1.07$ & - & - & 0.38 \\
\hline Fok 1 & $\mathrm{FF}(n=152)$ & $\mathrm{Ff}(n=111)$ & $\mathrm{ff}(n=3)$ & & \\
\hline 25-OH D (ng/ml) & $24(14-34)$ & $22(14-33)$ & $15(11-29)$ & 0.31 & 0.30 \\
\hline PTH (pg/ml) & $327(121-975)$ & $360(166-735)$ & $61(28-94)$ & 0.12 & 0.86 \\
\hline Calcium (mmol/l) & $2.21 \pm 0.27$ & $2.23 \pm 0.20$ & $2.17 \pm 0.43$ & 0.78 & 0.55 \\
\hline Corrected ca (mmol/l) & $2.21 \pm 0.61$ & $2.19 \pm 0.76$ & $2.17 \pm 0.27$ & 0.97 & 0.83 \\
\hline Phosphate (mmol/l) & $1.35 \pm 0.51$ & $1.38 \pm 0.48$ & $1.61 \pm 0.51$ & 0.64 & 0.64 \\
\hline TAP (U/L) & $123(91-160)$ & $103(79-167)$ & $258(69-312)$ & 0.47 & 0.35 \\
\hline FGF 23 & $105(35-845)$ & $161(54-1109)$ & $81(22-130)$ & 0.36 & 0.29 \\
\hline \multicolumn{6}{|l|}{ Medications } \\
\hline Calcium carbonate & $65(42.8)$ & $59(44.1)$ & $1(33.3)$ & 0.23 & 0.11 \\
\hline Alfacalcidol & $60(39.5)$ & $45(40.5)$ & $1(33.3)$ & 0.91 & 0.74 \\
\hline Calcium carbonate (mg/day) & $3545 \pm 739$ & $3692 \pm 778$ & - & - & 0.58 \\
\hline Alfacalcidol ( $\mu \mathrm{g} /$ week) & $1.98 \pm 1.12$ & $1.93 \pm 1.12$ & - & - & 0.91 \\
\hline Taq 1 & $\Pi(n=146)$ & $\mathrm{Tt}(n=95)$ & $\mathrm{tt}(n=27)$ & & \\
\hline 25- OHD (ng/ml) & $23(15-32)$ & $25(16-36)$ & $21(15-32)$ & 0.31 & 0.23 \\
\hline PTH(pg/ml) & $363(174-926)$ & 327 (109-913) & $672(121-1314)$ & 0.24 & 0.17 \\
\hline Calcium & $2.22 \pm 0.23$ & $2.22 \pm 0.25$ & $2.26 \pm 0.28$ & 0.74 & 0.87 \\
\hline Corrected ca & $2.21 \pm 0.61$ & $2.17 \pm 0.82$ & $2.36 \pm 0.31$ & 0.47 & 0.71 \\
\hline Phosphate (ng/ml) & $1.31 \pm 0.45$ & $1.38 \pm 0.56$ & $1.52 \pm 0.47$ & 0.13 & 0.36 \\
\hline TAP $(U / L)$ & $110(82-154)$ & $123(93-192)$ & $121(75-167)$ & 0.39 & 0.17 \\
\hline FGF 23 & $100(39-867)$ & $150(35-511)$ & $263(98-3834)$ & 0.055 & 0.91 \\
\hline \multicolumn{6}{|l|}{ Medications } \\
\hline Calcium carbonate & $61(41.8)$ & $52(54.7)$ & $14(51.9)$ & 0.41 & 0.18 \\
\hline Alfacalcidol & $54(37.0)$ & $43(45.3)$ & $11(40.7)$ & 0.50 & 0.24 \\
\hline Calcium carbonate (mg/day) & $3474 \pm 716$ & $3900 \pm 775$ & $3500 \pm 775$ & 0.33 & 0.15 \\
\hline Alfacalcidol ( $\mu \mathrm{g} /$ week) & $1.68 \pm 0.94$ & $2.44 \pm 1.32$ & $2.25 \pm 1.06$ & 0.23 & 0.10 \\
\hline Apa I & $\mathrm{AA}(n=112)$ & $\mathrm{Aa}(\mathrm{n}=152)$ & aa $(n=5)$ & & \\
\hline $25-\mathrm{OHD}(\mathrm{ng} / \mathrm{ml})$ & $24(17-37)$ & $22(15-32)$ & $19(15-28)$ & 0.22 & \\
\hline PTH (pg/ml) & $329(137-957)$ & $383(99-814)$ & 1889 (1359-1889) & 0.04 & 0.63 \\
\hline Phosphate $(\mathrm{mmol} / \mathrm{l})$ & $1.34 \pm 0.52$ & $1.37 \pm 0.48$ & $1.63 \pm 0.47$ & 0.46 & 0.52 \\
\hline Calcium & $2.23 \pm 0.25$ & $2.21 \pm 0.24$ & $2.38 \pm 0.14$ & 0.27 & 0.52 \\
\hline
\end{tabular}


Table 3 Levels of markers of CKD-MBD across various VDR genotypes (Continued)

\begin{tabular}{|c|c|c|c|c|c|}
\hline Variable & Genotypes & & & p-value & P-value \\
\hline Corrected ca & $2.22 \pm 0.66$ & $2.19 \pm 0.68$ & $2.41 \pm 0.16$ & 0.79 & 0.76 \\
\hline TAP $(U / L)$ & $123(82-190)$ & $115(88-149$ & $160(91-440)$ & 0.51 & 0.91 \\
\hline FGF 23 & 109 (35-929) & $121(44-761)$ & $335(72-687)$ & 0.69 & 0.65 \\
\hline \multicolumn{6}{|l|}{ Medications } \\
\hline Calcium carbonate & $49(43.8)$ & $74(48.7)$ & $5(100.0)$ & 0.04 & 0.23 \\
\hline Alfacalcidol & $41(36.6)$ & $64(42.1)$ & $4(80.0)$ & 0.29 & 0.33 \\
\hline Calcium carbonate (mg/day) & $3700 \pm 775$ & $3525 \pm 734$ & $3375 \pm 750$ & 0.68 & 0.50 \\
\hline Alfacalcidol ( $\mu \mathrm{g} /$ week) & $2.03 \pm 1.06$ & $1.93 \pm 1.15$ & $2.50 \pm 0.87$ & 0.71 & 0.83 \\
\hline
\end{tabular}

Variables are presented as means \pm standard deviations or median(interquartile range), TAP serum total alkaline phosphate, $P T H$ parathyroid hormone, 25 (OH)D 25 hydroxyvitamin D 3, p-valuec: comparison between Homozygous dominant and heterozygous genotypes

The biochemical markers of CKD-MBD in the various genotypes are shown in Table 3. Median PTH, FGF 23and mean phosphate levels were significantly higher in patients with $\mathrm{Bb}$ genotype. Although the mean weekly dose of alfacalcidol was comparable between $\mathrm{BB}$ and $\mathrm{Bb}$ genotypes, the proportion of patients on alfacalcidol was higher in patients with $\mathrm{Bb}$ genotypes (45.5 versus 32.2, $p=0.047)$. In a restricted comparison between homozygous dominant genotype and heterozygous genotype due to smaller numbers of homozygous recessive genotype, the $P$ values did not change significantly.

In a restricted analysis involving hemodialysis patients, the univariable and multivariable analyses for the odds of developing moderate (controlled) and severe (uncontrolled) secondary hyperparathyroidism are shown in Table 4. Moderate (controlled) secondary hyperparathyroidism was defined as PTH between $130 \mathrm{pg} / \mathrm{ml}$ and $585 \mathrm{pg} / \mathrm{ml}$ (2-9 times the upper limit of normal) and severe (uncontrolled) secondary hyperparathyroidism as $\mathrm{PTH}>585 \mathrm{pg} / \mathrm{ml}$ (9 times the upper limit of normal). After adjusting for serum calcium, phosphate, fibroblast growth factor 23, and use of alfacalcidol, the $\mathrm{Bb}$ genotype was a significant predictor of developing both moderate (OR,3.88; $95 \mathrm{CI} 1.13-13.25, p=0.03$ ) and severe hyperparathyroidism(OR, 2.54; 95 CI 1.08-5.96, $p=0.03)$. The use of alfacalcidol was not eligible for inclusion into the final model, but was forced into the model due to a biologically plausible association between secondary hyperparathyroidism and the use of alfacalcidol.

The post estimation test shows no lack of fit with the final models $(p>0.05)$.

Figure 2a-d show gels for restriction endonuclease digestion for FokI, Apa I, Bsm I and Taq I polymorphisms respectively.

\section{Discussion}

In an attempt to unravel the complexity behind the pathophysiologic mechanisms of CKD-MBD, several investigators have looked at the relationship between
VDR polymorphisms and the calcium/PTH/calcitriol axis with inconsistent findings $[5,12]$. In this present study, consistent with some previous reports, we found a significant difference in PTH levels across Bsm I genotypes, patients with $\mathrm{Bb}$ genotype had a higher median PTH level compared to patients with $\mathrm{BB}$ and bb genotypes. In addition, $\mathrm{Bb}$ genotype was independently associated with the risk of developing moderate and severe secondary hyperparathyroidism in patients with ESKD. The influence of BsmI on parathyroid function was also observed in pre dialysis CKD and transplant patients. Marco et al. [16] reported a slower progression of secondary hyperparathyroidism in pre dialysis CKD patients with BB genotype, while Messa et al. [17] reported lower PTH levels in transplant patients with $\mathrm{BB}$ genotypes. On the other hand, contrary to our findings, some studies have reported non-significant differences in PTH levels across BsmI genotypes. However, it is noteworthy that Bsm I genotypes distribution varies greatly across ethnic groups, hampering comparisons of studies.

The molecular mechanisms by which Bsm I VDR polymorphisms influence hyperparathyroidism have been linked to presence of $b$ alleles. Previous studies have reported a strong association between $b$ alleles and decreased VDR gene transcription and/or m RNA stability, hence, affecting the regulatory actions of calcitriol on parathyroid glands [6, 17]. For example, patients with the $\mathrm{BB}$ genotypes are less susceptible to having reduced $1 \alpha$-hydroxylase compared to patients with bb genotypes. Therefore, patients with $\mathrm{b}$ alleles are less likely to have optimal levels of calcitriol required to inhibit PTH secretion and parathyroid cell proliferation.

A few studies have also investigated the associations between FokI, ApaI and secondary hyperparathyroidism in patients with CKD. Consistent with a previous study [13], although not statistically significant, patients with 
Table 4 Odds ratios for association between VDR polymorphisms and secondary hyperparathyroidism in haemodialysis patients

\begin{tabular}{lllll}
\hline Polymorphisms & $\begin{array}{l}\text { Crude OR } \\
95 \%(C l)\end{array}$ & P-value & Adjusted $^{\text {a }}$ & P-value \\
& & OR 95\% (Cl) & \\
\hline
\end{tabular}

Moderate (controlled) secondary hyperparathyroidism (PTH > $130 \mathrm{ng} / \mathrm{ml}$ ) Bsm I

\begin{tabular}{cllll}
$\mathrm{BB}$ & 1.00 (reference) & \multicolumn{3}{l}{1.00 (reference) } \\
$\mathrm{Bb}$ & $3.12(1.11-8.83)$ & 0.03 & $3.88(1.13-13.25)$ & 0.03 \\
$\mathrm{bb}$ & $\mathrm{N} / \mathrm{A}$ & $\mathrm{N} / \mathrm{A}$ & $\mathrm{N} / \mathrm{A}$ & \\
$\mathrm{Fokl}$ & & & & \\
$\mathrm{FF}$ & 1.00 (reference) & & 1.00 (reference) & \\
$\mathrm{Ff}$ & $0.87(0.31-2.39)$ & 0.78 & $0.65(0.20-2.10)$ & 0.47 \\
$\mathrm{ff}$ & $\mathrm{N} / \mathrm{A}$ & $\mathrm{N} / \mathrm{A}$ & $\mathrm{N} / \mathrm{A}$ & \\
Taq I & & & & \\
$\mathrm{TT}$ & 1.00 (reference) & & 1.00 (reference) & \\
$\mathrm{Tt}$ & $0.27(0.09-0.84)$ & 0.02 & $0.43(0.12-1.52)$ & 0.19 \\
$\mathrm{tt}$ & $0.53(0.09-2.96)$ & 0.47 & $0.76(0.11-5.19)$ & 0.78 \\
Apa I & & & & \\
$\mathrm{AA}$ & 1.00 (reference) & & 1.00 (reference) & \\
$\mathrm{Aa}$ & $0.42(0.13-1.36)$ & 0.15 & $0.25(0.06-1.01)$ & 0.052 \\
aa & $0.28(0.3-3.14)$ & 0.30 & $0.25(0.01-3.10)$ & 0.25
\end{tabular}

Severe (uncontrolled) hyperparathyroidism (PTH > $585 \mathrm{pg} / \mathrm{ml}$ )

Bsm I

\begin{tabular}{|c|c|c|c|c|}
\hline BB & 1.00 (reference) & & 1.00 (reference) & \\
\hline $\mathrm{Bb}$ & $2.55(1.19-5.47)$ & 0.02 & $2.54(1.08-5.96)$ & 0.032 \\
\hline bb & N/A & N/A & N/A & N/A \\
\hline \multicolumn{5}{|l|}{ Fok I } \\
\hline $\mathrm{FF}$ & 1.00 (reference) & & 1.00 (reference) & \\
\hline $\mathrm{Ff}$ & $0.42(0.21-0.82)$ & 0.01 & $0.37(0.17-0.81)$ & 0.01 \\
\hline ff & N/A & N/A & N/A & \\
\hline \multicolumn{5}{|l|}{ Taq I } \\
\hline$\pi$ & 1.00 (reference) & & 1.00 (reference) & \\
\hline $\mathrm{Tt}$ & $0.64(0.31-1.32)$ & 0.23 & $0.71(0.32-1.59)$ & 0.41 \\
\hline $\mathrm{tt}$ & $1.37(0.44-4.24)$ & 0.58 & $1.39(0.41-4.73)$ & 0.39 \\
\hline \multicolumn{5}{|l|}{ Apa I } \\
\hline AA & 1.00 (reference) & & 1.00 (reference) & \\
\hline $\mathrm{Aa}$ & $0.85(0.43-1.69)$ & 0.65 & $0.74(0.35-1.57)$ & 0.43 \\
\hline aa & $2.26(0.24-21.47)$ & 0.48 & $2.84(0.27-30.22)$ & 0.86 \\
\hline
\end{tabular}

$O R$ odds ratio, $C l$ confidence interval, $N \backslash A$ not applicable

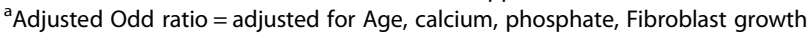
factor 23 and use of alfacalcidol

FF genotype had lower levels of PTH than patients with Ff in our study.

In addition to the complexity of CKD -MBD is the existence of the ethnic variability in the development and severity of secondary hyperparathyroidism among CKD patients. Several previous studies consistently showed that black patients have higher PTH levels and lower $25 \mathrm{OH}$ vitamin D levels $[18,19]$. The mechanisms behind these dissimilarities may partly be explained by genetic factors. For example, some polymorphisms may be over represented in certain races and therefore alter their risk. In this present study, there was a statistically significant difference between black and white participants in the distribution of the VDR polymorphisms. The $\mathrm{Bb}$ genotype which is an independent predictor of hyperparathyroidism is over expressed in black populations $(71.0 \%$ versus $56.4 \%, p<0.0001$ ). In line with our findings, previous studies have also reported ethnic variations in the distribution of VDR polymorphisms [20, 21]. Uitterlinden et al. [21] reported that the frequency of the f allele of Fok1 was lower in Africans as compared to Caucasians (Caucasians $34 \%$ versus Africans 24\%); similarly a significant difference was found in the frequency of the Bsm1, B allele was lower in the Asian population compared to other populations (Asians 7\%, Africans 36\%, and $42 \%$ in Caucasians). These observed ethnic variations in the frequency of the VDR polymorphisms may help in explaining the racial discrepancy in the markers of CKD-MBD.

Several studies have consistently associated vitamin D insufficiency to various skeletal and extra skeletal clinical end points, leading to a special interest in the determinants of vitamin $\mathrm{D}$ metabolites [21, 22]. Thus far, well-established determinants of $25(\mathrm{OH})$ Dlevels include dietary sources and sun exposure [22]. However, a genetic factor has been shown to play a vital role in the inter individual variation in circulating vitamin $\mathrm{D}$ levels. For example, in the classical twin study, Hunter et al. reported that the calcium/PTH/ calcitiol axis is under strong genetic influence, accounting for $52 \%$ of calcium excretion, $74 \%$ of bone formation, $58 \%$ of bone resorption, $60 \%$ of $\mathrm{PTH}$, and $65 \%$ of vitamin D variance [23]. Similarly, a more recent large GWAS study has revealed a significant association with some genetic variants with $25(\mathrm{OH})$ D levels [22]. These important findings were restricted to Caucasians, limiting their results to other ethnic groups. However, a few studies that explored these associations across races yielded similar results [24]. In agreement with these studies, we found an increased risk of developing severe vitamin D deficiency with Fok Ff genotype and combined $\mathrm{Ff}+\mathrm{ff}$ genotypes. In contrast, we did not find a significant difference in vitamin D levels across the various VDR genotypes.

The limitations of our study include the following. Firstly, the influence of some wild type genotype (homozygous minor) on the calcium/PTH/calcitiol axis could not be adequately determined due to their smaller numbers. Thus, a larger sample will be required to detect their associations with markers of CKD -MBD. Secondly, this was a cross-sectional 

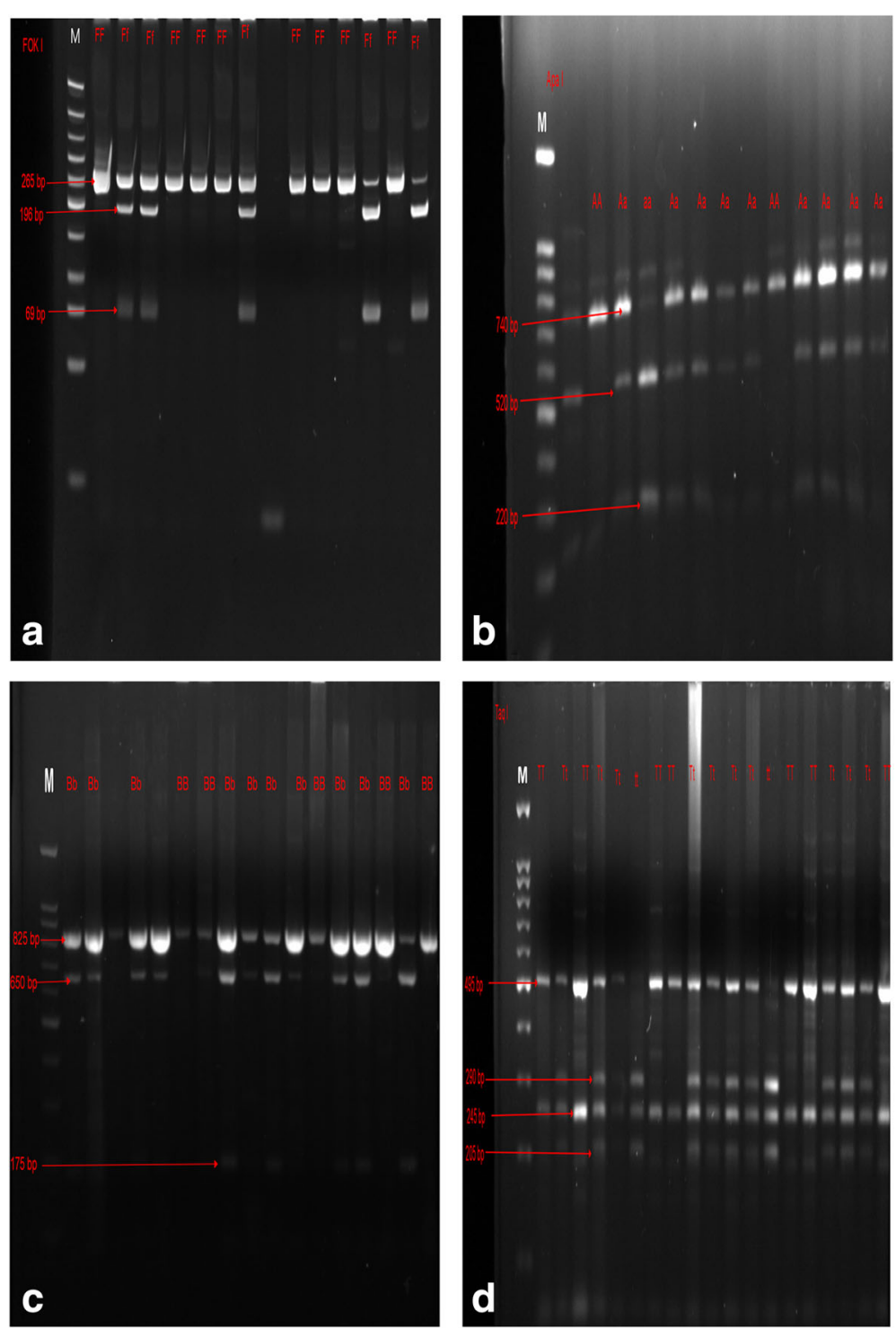

Fig. 2 a-d Restriction endonuclease digestion for Fokl, Apal, Bsm I and Taql polymorphisms, M= Marker

study design; therefore we could not determine the longitudinal changes in markers of CKD- MBD, as well as seasonal variation in $25(\mathrm{OH})$ D levels. Thirdly, Information relating to UVB exposure and vitamin $\mathrm{D}$ dietary history are lacking.

The strength of this study lies in the heterogeneous nature of our study population (black and white patients) in an African setting which has allowed comparisons of data not only for Black Africans with Black Americans, but also between whites in Africa and USA/Europe.

\section{Conclusion}

We have demonstrated that both moderate and severe secondary hyperparathyroidism are predicted by $B s m I$
$\mathrm{Bb}$ genotype, and the over expression of this genotype in black patients may partly explain the ethnic variations in the severity of secondary hyperparathyroidism in CKD population. In addition, Fok Ff genotype might be an important determinant of an individual's susceptibility to $25(\mathrm{OH}) \mathrm{D}$ deficiency.

\section{Abbreviations}

25(OH) D: 25- hydroxyvitamin D; CKD- MBD: Chronic kidney disease- mineral and bone disorder; CKD: Chronic kidney disease; DEQAS: Vitamin D external quality assurance scheme; DNA: Deoxyribonucleic acid;

ECLIA: Electrochemiluminescence immunoassay; EDTA: Ethylene diamine tetra acetic; eGFR: Estimated glomerular filtration rate; ESKD: End stage kidney disease; FGF 23: Fibroblast Growth Factor 23; HPLC: High performance liquid chromatography; IPTH: Intact Parathyroid hormone; MDRD: Modified Diet Renal Disease; MHD: Maintenance haemodialysis; OR: Odds ratio; VDR: Vitamin D receptor 


\section{Acknowledgments}

The International Society of Nephrology (ISN), for supporting Bala Waziri's ISN fellowship training at the University of the Witwatersrand. Drs Vakhtang Rekhviashvili, Shoyab Wadee and Graham Paget.

\section{Funding}

This study was partly supported by grants from the AstraZeneca Research Trust fund the National Kidney Foundation of South Africa (NKFSA) Adcok Ingram Research Grants. The funders had no role in the study design, collection, analysis or interpretation of data and writing of the manuscript.

\section{Availability of data and materials}

The datasets used and/or analyzed during the current study are available from the corresponding author on reasonable request.

\section{Authors' contributions}

BW conceptualized, drafted the manuscript and analyzed the data. SN, RD, $C D$, and TP were involved in reviewing the manuscript for intellectual content. BW, RD, CD and TP conducted the genetic analysis. All authors read and approved the final manuscript.

\section{Ethics approval and consent to participate}

The study protocol was approved by the Health Research and Ethics committee (HREC) of the University of the Witwatersrand; clearance certificate number M141016. All participants gave written informed consent prior to enrolment.

\section{Consent for publication}

Not applicable

\section{Competing interests}

The authors declare that they have no competing interests.

\section{Publisher's Note}

Springer Nature remains neutral with regard to jurisdictional claims in published maps and institutional affiliations.

Received: 15 August 2017 Accepted: 22 January 2018

Published online: 07 February 2018

\section{References}

1. Wang TJ, Pencina MJ, Booth SL, Jacques PF, Ingelsson E, Lanier K, Benjamin EJ, D'Agostino RB, Wolf M, Vasan RS, et al. Circulation. 2008;117(4):503-11.

2. Scragg R, Sowers M, Bell C. Serum 25-hydroxyvitamin D, diabetes, and ethnicity in the third National Health and nutrition examination survey. Diabetes Care. 2004;27(12):2813-8.

3. John EM, Schwartz GG, Dreon DM, Koo J. Vitamin D and breast cancer risk: the NHANES I epidemiologic follow-up study, 1971-1975 to 1992. National Health and nutrition examination survey. Cancer Epidemiol Biomark Prev. 1999:8(5):399-406.

4. Messa P, Alfieri C, Rastaldi MP. Recent insights into vitamin $D$ and its receptor. J Nephrol. 2011;24(18):S30-7.

5. Erturk S. Gene polymorphism association studies in dialysis: bone and mineral metabolism. Semin Dial. 2006;19(3):232-7.

6. Morrison NA, Qi JC, Tokita A, Kelly PJ, Crofts L, Nguyen TV, Sambrook PN, Eisman JA. Prediction of bone density from vitamin $\mathrm{D}$ receptor alleles. Nature. 1994;367(6460):284-7.

7. Fernandez E, Fibla J, Betriu A, Piulats JM, Almirall J, Montoliu J. Association between vitamin $\mathrm{D}$ receptor gene polymorphism and relative hypoparathyroidism in patients with chronic renal failure. J Am Soc Nephrol. 1997;8(10):1546-52.

8. Marco MP, Martinez I, Betriu A, Craver L, Fibla MJ, Fernandez E. Influence of Bsml vitamin $D$ receptor gene polymorphism on the response to a single bolus of calcitrol in hemodialysis patients. Clin Nephrol. 2001;56(2):111-6.

9. Nagaba $Y$, Heishi M, Tazawa H, Tsukamoto Y, Kobayashi Y. Vitamin D receptor gene polymorphisms affect secondary hyperparathyroidism in hemodialyzed patients. Am J Kidney Dis. 1998;32(3):464-9.

10. Yokoyama K, Shigematsu T, Tsukada T, Ogura Y, Takemoto F, Hara S, Yamada A, Kawaguchi Y, Hosoya T. Apa I polymorphism in the vitamin D receptor gene may affect the parathyroid response in Japanese with endstage renal disease. Kidney Int. 1998;53(2):454-8.
11. Marco MP, Craver L, Betriu A, Fibla J, Fernandez E. Influence of vitamin D receptor gene polymorphisms on mortality risk in hemodialysis patients. Am J Kidney Dis. 2001;38(5):965-74.

12. Chudek J, Karkoszka H, Schmidt-Gayk H, Ritz E, Kokot F. Plasma parathyroid hormone, phosphatemia and vitamin $\mathrm{D}$ receptor genotype: are they interrelated? J Nephrol. 2000;13(1):54-8.

13. Vigo Gago E, Cadarso-Suarez C, Perez-Fernandez R, Romero Burgos R, Devesa Mugica J, Segura IC. Association between vitamin D receptor Fokl. Polymorphism and serum parathyroid hormone level in patients with chronic renal failure. J Endocrinol Investig. 2005;28(2):117-21.

14. Levey AS, Coresh J, Greene T, Stevens LA, Zhang YL, Hendriksen S, Kusek $J W$, Van Lente F. Using standardized serum creatinine values in the modification of diet in renal disease study equation for estimating glomerular filtration rate. Ann Intern Med. 2006;145(4):247-54.

15. Waziri B, Duarte R, Naicker $S$. High serum alkaline Phosphatase, Hypercalcaemia, race, and mortality in south African maintenance Haemodialysis patients. Int J Nephrol. 2017;2017:2795432.

16. Marco MP, Martinez I, Amoedo ML, Borras M, Saracho R, Almirall J, Fibla J, Fernandez E. Vitamin D receptor genotype influences parathyroid hormone and calcitriol levels in predialysis patients. Kidney Int. 1999;56(4):1349-53.

17. Messa P, Sindici C, Cannella G, Miotti V, Risaliti A, Gropuzzo M, Di Loreto PL, Bresadola F, Mioni G. Persistent secondary hyperparathyroidism after renal transplantation. Kidney Int. 1998;54(5):1704-13.

18. Jovanovich A, Chonchol M, Cheung AK, Kaufman JS, Greene T, Roberts WL, Smits G, Kendrick J. Racial differences in markers of mineral metabolism in advanced chronic kidney disease. Clin J Am Soc Nephrol. 2012;7(4):640-7.

19. Jorgetti V, dos Reis LM, Ott SM. Ethnic differences in bone and mineral metabolism in healthy people and patients with CKD. Kidney Int. 2014;85(6): 1283-9.

20. Zmuda JM, Cauley JA, Ferrell RE. Molecular epidemiology of vitamin D receptor gene variants. Epidemiol Rev. 2000;22(2):203-17.

21. Uitterlinden AG, Fang Y, Van Meurs JB, Pols HA, Van Leeuwen JP. Genetics and biology of vitamin D receptor polymorphisms. Gene. 2004:338(2):14356

22. Wang TJ, Zhang F, Richards JB, Kestenbaum B, van Meurs JB, Berry D, Kiel DP, Streeten EA, Ohlsson C, Koller DL, Peltonen L, Cooper JD, O'Reilly PF, Houston DK, Glazer NL, Vandenput L, Peacock M, Shi J, Rivadeneira F, ML MC, Anneli P, de Boer IH, Mangino M, Kato B, Smyth DJ, Booth SL, Jacques PF, Burke GL, Goodarzi M, Cheung CL, Wolf M, Rice K, Goltzman D, Hidiroglou N, Ladouceur M, Wareham NJ, Hocking LJ, Hart D, Arden NK, Cooper C, Malik S, Fraser WD, Hartikainen AL, Zhai G, Macdonald HM, Forouhi NG, Loos RJ, Reid DM, Hakim A, Dennison E, Liu Y, Power C, Stevens HE, Jaana L, Vasan RS, Soranzo N, Bojunga J, Psaty BM, Lorentzon M, Foroud T, Harris TB, Hofman A, Jansson JO, Cauley JA, Uitterlinden AG, Gibson Q, Jarvelin MR, Karasik D, Siscovick DS, Econs MJ, Kritchevsky SB, Florez JC, Todd JA, Dupuis J, Hypponen E, Spector TD. Common genetic determinants of vitamin $D$ insufficiency: a genome-wide association study. Lancet. 2010:376(9736):180-8.

23. Hunter D, De Lange M, Snieder H, MacGregor AJ, Swaminathan R, Thakker RV, Spector TD. Genetic contribution to bone metabolism, calcium excretion, and vitamin $\mathrm{D}$ and parathyroid hormone regulation. J Bone Miner Res. 2001;16(2):371-8.

24. Sarkissyan M, Wu Y, Chen Z, Mishra DK, Sarkissyan S, Giannikopoulos I, Vadgama JV. Vitamin D receptor Fokl gene polymorphisms may be associated with colorectal cancer among African American and Hispanic participants. Cancer. 2014;120(9):1387-93.

\section{Submit your next manuscript to BioMed Central and we will help you at every step:}

- We accept pre-submission inquiries

- Our selector tool helps you to find the most relevant journal

- We provide round the clock customer support

- Convenient online submission

- Thorough peer review

- Inclusion in PubMed and all major indexing services

- Maximum visibility for your research

Submit your manuscript at www.biomedcentral.com/submit
Biomed Central 